\title{
APRESENTAÇÃO | PRESENTATION
}

Este número dos Cadernos de Língua e Literatura Hebraica trata, basicamente, da literatura judaica e israelense. Assim, o leitor se deparará com uma ampla gama de autores, épocas e contextos sócio-históricos: desde o teatro em língua ídiche do século XIX na Europa do Leste até análises de obras produzidas na Argentina e no Brasil no século XX, passando pela dramaturgia de Arthur Miller nos Estados Unidos, na metade do século XX, a literatura alemã escrita no Egito no mesmo período e a literatura israelense de nossos dias.

Contamos também com duas contribuições especiais: uma entrevista de Aharon Appelfeld, publicada no Forward, em junho de $2016^{1}$, e o texto crítico de David Foster sobre Rawet. Este último revela o comprometimento aberto do escritor com uma visão de mundo que ele aborda a partir da interseccionalidade entre ser judeu, ser exilado e ser queer. Não seria um exagero afirmar que se Rawet foi o "fundador da bibliografia sobre uma teoria queer brasileira". David Foster é aquele que descobriu essa faceta na obra de Rawet, apresentando-a com a lucidez e erudição que caracterizam seus escritos.

Como em outras oportunidades, também naquelas entrevistas de Aharon Appelfeld publicadas pelos Cadernos, o leitor não pode deixar de comover-se e, ao mesmo tempo, sentir admiração pelas historias e anedotas de Appelfeld sobre a Europa que não o quis e o deixou órfão, sendo ele um adolescente que, depois de Shoá, emigrou a Israel e lá construiu a sua trajetória literária. As reflexões sobre a importância do hebraico e do ídiche, tanto nas décadas da criação do Estado de Israel como na atualidade, constituem um depoimento instigante numa época em que convivem judeus que enxergam um processo de dessionização crescente e judeus que defendem o revival da língua ídiche.

$\mathrm{O}$ artigo de autoria de Karla Louise de Ameida Petel analisa o fenômeno dos "pais enlutados" no romance de David Grossman, A mulher foge. A tentativa de compreender uma realidade para a qual não existe uma expressão nas línguas indo-europeias, mas que é uma realidade institucionalizada na sociedade israelense, extrapola a dimensão ficcional e adentra em análises sociológicas que contrapõem o romance mencionado, a biografia do autor e um

\footnotetext{
1 Disponível em: <http://yiddish.forward.com/articles/197536/aaron-applefeld-a-yiddish-writer-in-hebrew/> Acesso em: 01 dez. 2016.
} 
dos fenômenos mais trágicos no cenário israelense, revelando um mundo desconhecido para a maioria dos leitores de língua brasileira.

O texto de Nancy Rozenchan, por sua vez, com seu título provocativo, esmiúça as características das línguas das periferias da sociedade israelense contemporânea. O foco da autora são os etnoletos falados em diversas comunidades de judeus originários de países árabes e a dificuldade encontrada ao se traduzirem palavras desses etnoletos, as quais são empregadas pelos diferentes segmentos étnico-religiosos que compõem o mosaico cultural e linguístico israelense e que, cada vez mais, aparecem como personagens na literatura israelense.

$\mathrm{O}$ artigo de Priscila Nascimento Marques trata de aspectos da formação do teatro judaico de língua ídiche na Rússia da primeira metade do século XX, para depois comentar as resenhas escritas por L. S. Vygótski acerca das apresentações da companhia de teatro dirigida por Menachem Rubin, as quais tiveram lugar na cidade de Gomel, no ano de 1923. As resenhas acompanham as inovações trazidas pelo teatro judaico no contexto das vanguardas russas, assim como seus paradoxos e inconsistências.

Luis Krausz, em seu texto, analisa duas representações literárias da vida judaica em Alexandria: os romances Kaitz Alexandroni, de Itzhak Gormezano-Goren, e Out of Egypt, de André Aciman. Gormezano-Goren e Aciman apresentam, em suas narrativas, a vida da burguesia judaica da cidade de Alexandria na segunda metade do século XX. A ascensão de Gamal Abdel Nasser ao poder e a expulsão dos judeus do Egito os expuseram a um novo exílio, lançando-os à procura da redenção.

Leopoldo Osorio Carvalho de Oliveira aborda o romance A majestade do Xingu, de Moacyr Scliar, e, na sua análise, trata da formação da identidade e imaginários judaicos no Brasil como elementos integrantes da sociedade nacional, dentro da qual procuram afirmar seu próprio caminho.

Gabriel Steinberg analisa o romance Maassê Betabaat, no qual o escritor israelense contemporâneo Ilan Sheinfeld traça a trajetória de duas famílias que se deslocam desde a Europa até Buenos Aires, na última década do século XIX. Entre os milhares de imigrantes que, à procura de uma nova vida, chegaram à América, estavam aqueles que procuraram prosperar através da exploração da prostituição. Nesse romance, é revelado um nebuloso e terrível segredo: três gerações de prostitutas judias carregam sobre si a marca da vergonha. 
No artigo que versa sobre Arthur Miller, Thiago Pereira Russo identifica elementos da cultura judaica presentes em suas peças teatrais e também em sua identidade. Sua ligação com a temática judaica aflora ao tratar da questão da Shoá, sinalizando uma virada em sua escrita, assim como sua aproximação do humanismo judaico.

Suzana Chwarts, em seu texto, destaca as questões de gênero na narrativa bíblica da criação, assim como os papeis tanto do homem quanto da mulher na família nuclear e estendida. Em seguida, a autora trata dos conceitos bíblicos de beit av e goel, a fim de demonstrar como os profetas foram capazes de se utilizar deles na formulação de uma teologia da salvação.

Reginaldo Gomes de Araújo compara palavras e expressões dos ditos de Jesus transmitidos pelos Sinóticos com os escritos rabínicos (Talmudim, Mishnaiot, Midrashim etc.). Nesse estudo comparativo, pode-se constatar, claramente, que os ditos de Jesus apresentados pelos Evangelhos Sinóticos faziam parte da tradição judaica.

O texto da historiadora Susana Brauner nos aproxima de um tópico pouco pesquisado nos Estudos Judaicos em geral e nos Estudos Judaicos latino-americanos em particular: a identidade de judeus descendentes de países árabes que se assimilaram, através de estratégias diversas - algumas laicas, outras religiosas -, às sociedades que escolheram para findar novas raízes. O mencionado texto, apesar de fazer um racconto das múltiplas identidades desses judeus ao longo da história, foca a atenção na contemporaneidade e em um contexto geográfico específico: a Argentina.

O artigo que concerne ao cinema ortodoxo, escrito por Bruno Szlak, revela novas facetas da ortodoxia israelense através da análise de um novo tipo de produção ortodoxa: filmes destinados exclusivamente a judeus observantes, com toda a complexidade intrínseca a esse fenômeno.

É nosso anseio, com esta coletânea de artigos, divulgar para o público brasileiro em geral e para os pesquisadores de temas judaicos em particular pesquisas sobre os judeus, o judaísmo e a literatura judaica desenvolvidas não só no Brasil, mas em outros contextos nacionais e a partir de diferentes perspectivas disciplinares.

Marta F. Topel e Gabriel Steinberg 